\title{
Newly diagnosed primary intracranial neoplasms in pregnant women: a population-based assessment
}

\author{
JF HAAS，W JÄNISCH，W STANECZEK* \\ From the National Cancer Registry, Central Institute for Cancer Research, ${ }^{*}$ and the Institute of Pathology, \\ Humbolt University of Berlin, German Democratic Republic
}

SUMMARY The presence of a pregnancy at the time of the initial diagnosis of an intracranial neoplasm was studied using material from a population-based tumour registry. Seventeen malignant neoplasms of the brain (ICD 191), three meningiomas, three acoustic neurinomas and a pituitary adenoma associated with pregnancy were reported to the National Cancer Registry of the GDR from 1961-1979. Observed cases were compared with those expected based on the number of births and the incidence rates for intracranial tumours among women of childbearing age during the same time period. Observed to expected ratios were substantially reduced for malignancy of the brain and meningioma but not for acoustic neurinoma. Review of this uniformly collected material did not provide support for the view that intracranial neoplasms present more often during pregnancy.

The diagnosis of a brain tumour in a pregnant patient is a dramatic event for the patient, her family and for the attending physicians. The nature and timing of therapy directed at the brain tumour are affected by the existence of the pregnancy. Similarly, decisions about whether to continue the pregnancy and the selection of the best means of delivery are critically influenced by the nature and prognosis of the mother's intracranial lesion. In addition the question of a causal link between pregnancy and the development or progression of the tumour is inevitably raised. The present work approached the problem of the association of brain tumour with pregnancy from the epidemiologic point of view.

The literature concerning pregnancy and intracranial neoplasms consists largely of case reports, case series and reviews of previously collected material. ${ }^{1}$ Cases may have come from one or several referral centres and, in some instances, have been collected over decades. ${ }^{2}$ Different definitions are used by each author in the selection and review of cases. Depending on the criteria, patients may be included in whom brain tumour symptoms or diagnosis occurred before, during or after pregnancy. Given such diverse methods of case selection, the assess-

Address for reprint requests: Prof. Dr W Jänisch, Inst. of Pathology Humboldt University, Schumannstr. 22, Berlin, 1040, GDR.

Received 28 August 1985.

Accepted 5 November 1985 ments of the frequency with which the two processes are associated are necessarily highly subjective. Kloss, writing in 1952 from the perspective of a university clinic in Vienna, ${ }^{3}$ regarded the combination as "in no way rare". Verhagen, reviewing the 160 cases which he found in the literature up to 1974 , described the association as occurring "extremely seldom". 1

Epidemiological investigation of this problem promises a fresh perspective. The observed number of brain tumours associated with pregnancy can be compared with that expected based on the number of pregnancies and the frequency of brain tumours in the general female population of childbearing age. Analysis of uniformly and systematically collected information on newly diagnosed tumours in a defined population permits direct estimation of the incidence of pregnancy-associated intracranial neoplasms. The frequency of the association and the relative frequency of various tumour types can be assessed from material which is not biased by selection and referral. The present study investigates the frequency of primary intracranial neoplasms in association with pregnancy and considers the temporal relation between pregnancy and the onset of tumour symptoms.

\section{Methods}

A nation-wide, obligatory cancer reporting system has been operating in the German Democratic Republic (GDR) since 1953. Case reporting forms are completed by the diagnosing 874 
able 1 Newly diagnosed cases of primary intracranial neoplasms with existing pregnancy

\begin{tabular}{|c|c|c|c|c|c|c|c|}
\hline $\begin{array}{l}\text { Vase } \\
\text { lo }\end{array}$ & Tumour type & $\begin{array}{l}\text { Year of } \\
\text { diagnosis }\end{array}$ & $\begin{array}{l}\text { Age at } \\
\text { diagnosis }\end{array}$ & Occupation & $\begin{array}{l}\text { Months pregnant } \\
\text { at tumour diagnosis } \\
\text { Pregnancy outcome }\end{array}$ & $\begin{array}{l}\text { Symptoms, duration } \\
\text { prior to diagnosis }\end{array}$ & $\begin{array}{l}\text { Survival after } \\
\text { diagnosis }\end{array}$ \\
\hline \multicolumn{8}{|c|}{ Malignant brain tumours (ICD 191.0) } \\
\hline 1 & $\begin{array}{l}\text { Astrocytoma, } \\
\text { cerebellar }\end{array}$ & 1975 & 22 & Clerk & $8 / L$ & $\begin{array}{l}\text { Headache, vomiting, } \\
\text { convulsions, I month }\end{array}$ & $\begin{array}{l}\text { Alive and well, } \\
8 \text { years }\end{array}$ \\
\hline 2 & $\begin{array}{l}\text { Astrocytoma, } \\
\text { l. parietotemporal }\end{array}$ & 1964 & 24 & Machinist & $5 / 2$ & $\begin{array}{l}\text { Seizures, } \\
3 \text { years }\end{array}$ & $\begin{array}{l}\text { Death, } \\
26 \text { months }\end{array}$ \\
\hline 3 & $\begin{array}{l}\text { Astrocytoma, } \\
\text { l. temporal }\end{array}$ & 1965 & 24 & Typist & $2 / \pi(2)$ & $\begin{array}{l}\text { Headache, nausea, } \\
\text { dizziness, loss of } \\
\text { consciousness, } \\
8 \text { months }\end{array}$ & $\begin{array}{l}\text { Death, } \\
15 \text { months }\end{array}$ \\
\hline 4 & $\begin{array}{l}\text { Astrocytoma, } \\
\text { 1. cerebral } \\
\text { hemisphere }\end{array}$ & 1961 & 26 & $\begin{array}{l}\text { Kindergarten } \\
\text { teacher }\end{array}$ & $6 / L / C$ & $\begin{array}{l}\text { Paresis right leg, } \\
\text { 6-7 months }\end{array}$ & $\begin{array}{l}\text { Death, } \\
51 / 2 \text { years }\end{array}$ \\
\hline 5 & $\begin{array}{l}\text { Astrocytoma, pons, } \\
\text { medulla }\end{array}$ & 1975 & 27 & Clerk & 5 (at necropsy) & $\begin{array}{l}\text { Respiratory failure } \\
\text { requiring mechanical } \\
\text { ventilation, } 4 \text { months } \\
\text { prior to death }\end{array}$ & $\begin{array}{c}\text { Diagnosis at } \\
\text { necropsy }\end{array}$ \\
\hline 6 & Astrocytoma, pons & 1969 & 20 & Saleswoman & $3 / \mathrm{MD}(4)$ & $\begin{array}{l}\text { Paraesthesias and } \\
\text { sensory loss in face, } \\
4-5 \text { months }\end{array}$ & $\begin{array}{l}\text { Death, } \\
1 \text { month }\end{array}$ \\
\hline 7 & $\begin{array}{l}\text { Astrocytoma, hypo- } \\
\text { thalamus, invading } \\
\text { 3rd ventricle }\end{array}$ & 1978 & 23 & Clerk & $5 / \mathbf{T}(6)$ & $\begin{array}{l}\text { Headache, vomiting, } \\
\text { aphasia, } \\
1 \text { year }\end{array}$ & $\begin{array}{l}\text { Death, } \\
9 \text { months }\end{array}$ \\
\hline 8 & $\begin{array}{l}\text { Astrocytoma, } \\
\text { l. frontal }\end{array}$ & 1976 & 26 & Economist & $\begin{array}{l}7(43 \mathrm{~cm}, 1240 \mathrm{gm} \\
\text { at autopsy) }\end{array}$ & $\begin{array}{l}\text { Seizures, status } \\
\text { epilepticus, } 1 \text { week }\end{array}$ & $\begin{array}{l}\text { Diagnosis at } \\
\text { necropsy }\end{array}$ \\
\hline 9 & $\begin{array}{l}\text { Astrocytoma, } \\
\text { cerebellar }\end{array}$ & 1966 & 30 & Housewife & $\begin{array}{l}8(36 \mathrm{~cm}, 950 \mathrm{gm} \\
\text { at necropsy, } \\
\text { developmental } \\
\text { abnormalities) }\end{array}$ & $\begin{array}{l}\text { Headache, two years } \\
\text { diplopia, nausea, } \\
\text { vomiting, } \\
8-9 \text { months }\end{array}$ & $\begin{array}{c}\text { Diagnosis at } \\
\text { necropsy }\end{array}$ \\
\hline 0 & $\begin{array}{l}\text { Glioblastoma, } \\
\text { 1. temporal }\end{array}$ & 1967 & 28 & Saleswoman & $7 / \mathbf{s / c}$ & $\begin{array}{l}\text { Headache, dizziness, } \\
\text { vomiting, } \\
9-10 \text { months }\end{array}$ & $\begin{array}{l}\text { Death, } \\
9 \text { months }\end{array}$ \\
\hline 1 & $\begin{array}{l}\text { Glioblastoma, } \\
\text { re. fronto-temporo- } \\
\text { parietal }\end{array}$ & 1968 & 21 & Cashier & $5 / T(5)$ & $\begin{array}{l}\text { Headache, vomiting, } \\
\text { dizziness, } \\
\text { 3-4 months }\end{array}$ & $\begin{array}{l}\text { Death, } \\
7 \text { months }\end{array}$ \\
\hline 2 & $\begin{array}{l}\text { Glioblastoma, } \\
\text { l. parietal }\end{array}$ & 1964 & 23 & $\begin{array}{l}\text { Nursery } \\
\text { assistant }\end{array}$ & 6 & $\begin{array}{l}\text { Tremors, paraesthesias } \\
\text { of arm, } 5 \text { months }\end{array}$ & $\begin{array}{l}\text { Diagnosis at } \\
\text { necropsy }\end{array}$ \\
\hline 3 & $\begin{array}{l}\text { Glioblastoma, } \\
\text { cerebellopontine angle }\end{array}$ & 1966 & 26 & $\begin{array}{l}\text { Railroad } \\
\text { employee }\end{array}$ & $5 / \pi(s)$ & $\begin{array}{l}\text { Vomiting, headache, } \\
1 \text { month }\end{array}$ & $\begin{array}{l}\text { Death, } \\
6 \text { months }\end{array}$ \\
\hline 4 & $\begin{array}{l}\text { Glioblastoma, } \\
\text { r. temporal }\end{array}$ & 1970 & 34 & Clerk & $\begin{array}{l}3(8 \mathrm{~cm} \text {, dizygotic } \\
\text { twins at necropsy) }\end{array}$ & $\begin{array}{l}\text { Headache, aphasia, } \\
\text { confusion, } 3 \text { months }\end{array}$ & $\begin{array}{l}\text { Diagnosis at } \\
\text { necropsy }\end{array}$ \\
\hline 5 & $\begin{array}{l}\text { Glioblastoma, } \\
\text { 1. frontal }\end{array}$ & 1979 & 39 & Physician & $8 / L$ & $\begin{array}{l}\text { Headache, nausea, } \\
\text { vomiting, behaviour } \\
\text { changes, } 4 \text { months }\end{array}$ & $\begin{array}{l}\text { Alive, } \\
5 \text { years }\end{array}$ \\
\hline 6 & $\begin{array}{l}\text { Ependymoma, } \\
\text { 1. parietooccipital }\end{array}$ & 1976 & 20 & $\begin{array}{l}\text { Cable factory } \\
\text { operator }\end{array}$ & $1 / L$ & $\begin{array}{l}\text { Nausea, vomiting, } \\
1 \text { year } \\
\text { severe headache, } \\
1 \text { month }\end{array}$ & $\begin{array}{l}\text { Death, } \\
31 / 2 \text { years }\end{array}$ \\
\hline 7 & $\begin{array}{l}\text { Sarcoma, } \\
\text { r. parietotemporal }\end{array}$ & 1964 & 22 & Hairdresser & $7 / \mathrm{L} / \mathrm{C}$ & $\begin{array}{l}\text { Vomiting, severe head- } \\
\text { ache, diplopia during } \\
\text { pregnancy, delivery } \\
\text { by caesarian section }\end{array}$ & $\begin{array}{l}\text { Death, } \\
11 \text { months }\end{array}$ \\
\hline 8 & $\begin{array}{l}\text { Meningioma, } \\
\text { l. fronto-temporal }\end{array}$ & 1961 & 22 & $\begin{array}{l}\text { ther primary intr } \\
\text { Housewife }\end{array}$ & $\begin{array}{l}\text { anial tumours } \\
4 / ?\end{array}$ & $\begin{array}{l}\text { Bulging } 1 . \text { temple, } \\
11 \text { months; headache, } \\
\text { visual disturbances, } \\
6 \text { months }\end{array}$ & $\begin{array}{l}\text { Alive, recurrence } \\
\text { at } 23 \text { years }\end{array}$ \\
\hline 9 & $\begin{array}{l}\text { Meningioma, } \\
\text { falx cerebri }\end{array}$ & 1965 & 33 & Farmworker & $2 / L$ & $\begin{array}{l}\text { Sensory loss both legs, } \\
6 \text { months; later } \\
\text { spastic paralysis }\end{array}$ & $\begin{array}{l}\text { Alive, } \\
15 \text { years }\end{array}$ \\
\hline 0 & $\begin{array}{l}\text { Meningioma, } \\
\text { r. fronto-temporal }\end{array}$ & 1977 & 40 & $\begin{array}{l}\text { Factory- } \\
\text { worker }\end{array}$ & $? / \mathrm{T}^{*}$ & $\begin{array}{l}\text { Headache, nausea, } \\
\text { vomiting, fatigue, } \\
2 \text { years }\end{array}$ & $\begin{array}{l}\text { Alive, } \\
6 \text { years }\end{array}$ \\
\hline 1 & $\begin{array}{l}\text { Acoustic neurinoma, } \\
\text { l. cerebellopontine } \\
\text { angle }\end{array}$ & 1967 & 30 & Housewife & $7 / ?$ & $\begin{array}{l}\text { Headache, vomiting, } \\
6 \text { months; hearing, } \\
\text { visual disturbances, } \\
1 \text { week }\end{array}$ & $\begin{array}{l}\text { Alive, } \\
10 \text { years }\end{array}$ \\
\hline 2 & $\begin{array}{l}\text { Acoustic neurinoma, } \\
\text { cerebellum }\end{array}$ & 1968 & 32 & Book-keeper & $7 / \mathbf{L}$ & $\begin{array}{l}\text { Vomiting, hearing loss, } \\
\text { ataxia beginning, } \\
19-20 \text { months }\end{array}$ & $\begin{array}{l}\text { Alive, } \\
8 \text { years }\end{array}$ \\
\hline 3 & $\begin{array}{l}\text { Acoustic neurinoma, } \\
\text { cerebellopontine } \\
\text { angle }\end{array}$ & 1962 & 36 & Teacher & $8 / T$ & $\begin{array}{l}\text { Ear pain, dizziness, } \\
\text { ataxia, } 4 \text { months }\end{array}$ & $\begin{array}{l}\text { Alive, } \\
5 \text { years }\end{array}$ \\
\hline
\end{tabular}




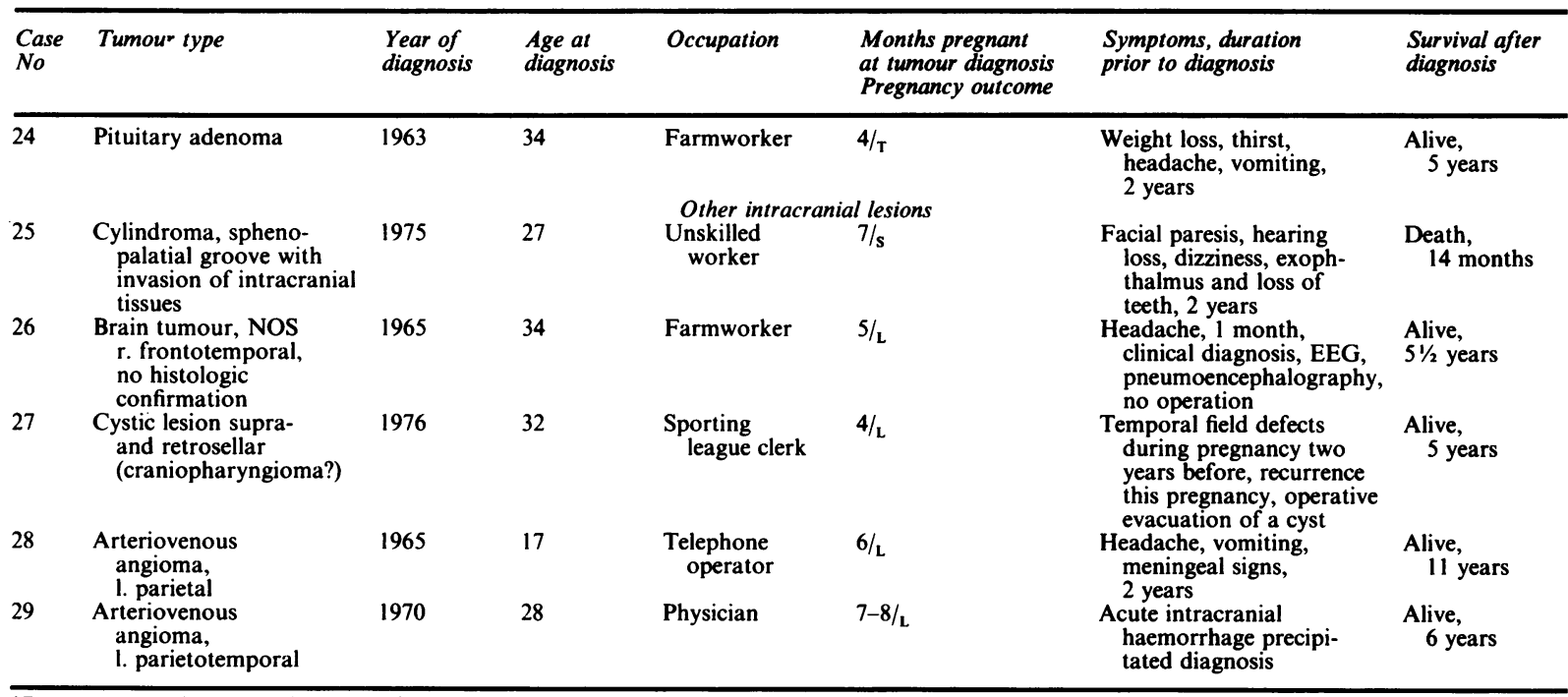

*Pregnancy was interrupted shortly after brain tumour diagnosis in this para 6, gravida 6 patient. Exact dates not known.

$\mathrm{L}$, liveborn; $\mathrm{C}$, caesarian delivery; $\mathrm{T}(\mathrm{m})$, terminated (month); $\mathrm{MD}(\mathrm{m})$, maternal death (month); $\mathrm{S}$, stillborn.

physician for each newly diagnosed cancer case and are forwarded through a network of local cancer care agencies to be compiled and interpreted at a national level by the National Cancer Registry (NCR). The population covered was approximately 16.7 million in 1979 . National Cancer Registry regulations require the reporting of all benign and malignant neoplasms of the brain, spinal cord, meninges and pituitary gland. Cancer reporting forms elicit standard items of information ${ }^{4}$ and also record the dates of onset of symptoms and of clinical diagnosis and treatment. Since 1956 cancer reporting forms have explicitly asked whether the patient was pregnant at the time of clinical diagnosis.

Cases analysed in the present work were those which were coded as pregnant. This code was based on an affirmative response to the query on the reporting forms and/or on information contained in pathology or necropsy reports. At the time the present study was initiated, computerized files were available for the years 1970-1979. Coded case lists for the period 1961-1969 were searched by hand to identify patients with intracranial neoplasms and pregnancy. In order to estimate the number of cases of brain tumour to be expected in pregnant females, the rates of intracranial neoplasia for women of childbearing age (15-44 years) were calculated for the GDR for the corresponding time periods. Pregnancy time-at-risk was estimated from the number of live births for the same years. The number of live births by mother's age at delivery were obtained from the Statistical Year Books of the GDR. ${ }^{5}$ A live birth was regarded as having contributed nine months at-risk time to the corresponding maternal age group.

The expected number of cancers was obtained using indirect standardisation. ${ }^{6}$ Observed to expected ratios were calculated with their corresponding 95\% (Miettinen) confidence intervals. ${ }^{7}$

Review of the NCR coding practices pertaining to malignant disease of the brain showed that angiomatous mal- formations of the brain and cylindromas with intracranial extension were being routinely classified to ICD 191, malignant neoplasms of the brain. General population incidence rates have been calculated on the basis of computergenerated rates which include these lesions under ICD 191. Bias would result if the numerator (observed, pregnancyassociated cancer cases) were corrected and the denominator (expected cases) were not. Thus parallel analyses are presented for corrected and uncorrected observed cases.

\section{Results}

Primary intracranial neoplasms in which the patient was pregnant at diagnosis are listed in table 1. A total of 17 histologically confirmed malignant neoplasms of the brain are known to have been diagnosed in pregnant patients in the GDR from 1961-1979, a frequency of 3.6 per $10^{6}$ births. There were also three meningiomas, three acoustic neurinomas and one pituitary adenoma. An additional meningioma which had been coded as pregnancy-associated was excluded upon review of the case. The patient had first presented in the immediate postpartum period and the tumour was diagnosed at necropsy. There is no doubt that the tumour was present during pregnancy; however diagnosis was postpartum and the case did not meet the definition used here. Additional intracranial lesions in pregnant patients include two arteriovenous haemangiomas and a cylindroma originating in the sphenopalatial region and invading the intracranial tissues.

Two cases without histological confirmation were reported and coded as malignant neoplasms of the 
brain. In both cases critical review raises doubts about the diagnosis. One case was a cystic retrosellar lesion (possibly a craniopharyngioma), which had been surgically evacuated. The patient subsequently did well for at least 5 years. In the second case the diagnosis was supported only by EEG and pneumoencephalography and the patient was also alive and well as least five years later.

Of the histologically confirmed malignant neo- plasms of the brain, nine were astrocytomas and five of these originated in the cerebral hemispheres. There were six glioblastomas, one ependymoma and an intracerebral sarcoma. In this material the three meningiomas constitute $13 \%$ of the pregnancyrelated primary intracranial neoplasms (excluding cases 25-29, table 1).

The duration of pregnancy at the time of clinical diagnosis and the duration of brain tumour symp-

Table 2 Onset of symptoms in relation to beginning of pregnancy by tumour type*

\begin{tabular}{|c|c|c|c|c|}
\hline \multirow[t]{2}{*}{ Tumour type } & \multicolumn{4}{|c|}{ Time of onset of symptoms in relation to pregnancy } \\
\hline & Before & Coincident & During & All \\
\hline $\begin{array}{l}\text { Astrocytoma } \\
\text { Glioblastoma } \\
\text { Ependymoma } \\
\text { Sarcoma } \\
\text { Meningioma } \\
\text { Acoustic neurinoma } \\
\text { Pituitary adenoma } \\
\text { All types }\end{array}$ & $\begin{array}{r}4 \\
1 \\
1 \\
3 \\
1 \\
1 \\
11\end{array}$ & $\begin{array}{l}2 \\
\frac{2}{-} \\
- \\
- \\
-\end{array}$ & $\begin{array}{l}3 \\
\frac{2}{1} \\
\frac{1}{2} \\
\frac{8}{8}\end{array}$ & $\begin{array}{r}9 \\
5 \\
1 \\
1 \\
3 \\
3 \\
1 \\
23\end{array}$ \\
\hline
\end{tabular}

*Excludes cases 25-29, table 1.

Table 3 Age-specific incidence of primary intracranial neoplasms, females aged 15 to 44 years, GDR

\begin{tabular}{|c|c|c|c|c|c|c|c|}
\hline \multirow[t]{2}{*}{ Tumour type } & \multicolumn{7}{|c|}{ Age group (yr) } \\
\hline & $15-19$ & $20-24$ & $25-29$ & $30-34$ & $35-39$ & $40-44$ & $15-44$ \\
\hline \multicolumn{8}{|c|}{$\begin{array}{l}\text { Malignant neoplasms of the brain } \\
1961-1969\end{array}$} \\
\hline $\begin{array}{l}\text { Number } \\
\text { Incidence per } 10^{5}\end{array}$ & $\begin{array}{l}67 \\
1.45\end{array}$ & $\begin{array}{l}87 \\
1 \cdot 70\end{array}$ & $\begin{array}{l}97 \\
1 \cdot 70\end{array}$ & $\begin{array}{l}125 \\
2 \cdot 48\end{array}$ & $\begin{array}{l}153 \\
3 \cdot 15\end{array}$ & $\begin{array}{r}191 \\
3.94\end{array}$ & $\begin{array}{l}720 \\
2 \cdot 38\end{array}$ \\
\hline $\begin{array}{l}\text { Number } \\
\text { Incidence per } 10^{5}\end{array}$ & $\begin{array}{l}102 \\
1 \cdot 56\end{array}$ & $\begin{array}{l}77 \\
1 \cdot 30\end{array}$ & $\begin{array}{l}98 \\
1.91\end{array}$ & $\begin{array}{l}143 \\
2 \cdot 51\end{array}$ & $\begin{array}{r}164 \\
2.67\end{array}$ & $\begin{array}{r}228 \\
4 \cdot 16\end{array}$ & $\frac{812}{2 \cdot 33}$ \\
\hline \multicolumn{8}{|l|}{$\begin{array}{l}\text { Meningioma } \\
1970-1979\end{array}$} \\
\hline Number & 7 & 6 & 16 & 26 & 78 & 117 & 250 \\
\hline Incidence per $10^{5}$ & 0.11 & $0 \cdot 10$ & $0 \cdot 31$ & 0.46 & 1.27 & $2 \cdot 14$ & 0.72 \\
\hline \multicolumn{8}{|l|}{$\begin{array}{l}\text { Acoustic neurinoma } \\
1970-1979\end{array}$} \\
\hline $\begin{array}{l}\text { Number } \\
\text { Incidence per } 10^{5}\end{array}$ & $\begin{array}{l}3 \\
0.05\end{array}$ & $\begin{array}{l}2 \\
0.03\end{array}$ & $\begin{array}{l}8 \\
0 \cdot 16\end{array}$ & $\begin{array}{l}13 \\
0 \cdot 23\end{array}$ & $\stackrel{21}{0 \cdot 34}$ & $\begin{array}{l}14 \\
0.26\end{array}$ & $\stackrel{61}{0.17}$ \\
\hline
\end{tabular}

Table 4 Observed and expected cases of primary malignant intracranial neoplasms (ICD 191) in association with pregnancy, GDR

\begin{tabular}{|c|c|c|c|c|c|c|c|c|c|}
\hline \multirow[t]{2}{*}{ Time period } & \multicolumn{7}{|c|}{ Age group (yr) } & \multirow[t]{2}{*}{$O / E$} & \multirow{2}{*}{$\begin{array}{l}95 \% \text { confidence } \\
\text { intervalt }\end{array}$} \\
\hline & $15-19$ & $20-24$ & $25-29$ & $30-34$ & $35-39$ & $40-44$ & All ages & & \\
\hline \multicolumn{10}{|l|}{$\begin{array}{l}1961-1969 \\
\text { Observed }\end{array}$} \\
\hline $\begin{array}{l}\text { Uncorrected } \\
\text { Corrected* } \\
\text { Expected } \\
1970-1979 \\
\text { Observed }\end{array}$ & $\begin{array}{l}0 \\
0 \\
3 \cdot 86\end{array}$ & $\begin{array}{l}6 \\
6 \\
12 \cdot 12\end{array}$ & $\begin{array}{l}3 \\
3 \\
8 \cdot 92\end{array}$ & $\begin{array}{l}2 \\
1 \\
6 \cdot 18\end{array}$ & $\begin{array}{l}0 \\
0 \\
3 \cdot 33\end{array}$ & $\begin{array}{l}0 \\
0 \\
0.90\end{array}$ & $\begin{array}{l}12 \\
10 \\
35 \cdot 3\end{array}$ & $\begin{array}{l}0.34 \\
0 \cdot 28\end{array}$ & $\begin{array}{l}(0.18-0.58) \\
(0.14-0.51)\end{array}$ \\
\hline $\begin{array}{l}\text { Uncorrected } \\
\text { Corrected } \dagger \\
\text { Expected }\end{array}$ & $\begin{array}{l}1 \\
1 \\
4 \cdot 18\end{array}$ & $\begin{array}{l}2 \\
2 \\
9 \cdot 47\end{array}$ & $\begin{array}{l}4 \\
2 \\
6 \cdot 50\end{array}$ & $\begin{array}{l}2 \\
1 \\
4 \cdot 11\end{array}$ & $\begin{array}{l}1 \\
1 \\
1 \cdot 73\end{array}$ & $\begin{array}{l}0 \\
0 \\
0.48\end{array}$ & $\begin{array}{c}10 \\
7 \\
26 \cdot 5\end{array}$ & $\begin{array}{l}0.38 \\
0.26\end{array}$ & $\begin{array}{l}(0.19-0.67) \\
(0.12-0.52)\end{array}$ \\
\hline
\end{tabular}

*Excludes, Table 1, cases 26, 28.

tExcludes, Table 1, cases 25, 27, 29.

$\ddagger$ Miettinen's exact limits. 
Table 5 Observed and expected cases of meningioma and acoustic neurinoma in association with pregnancy, GDR, 1961-1979

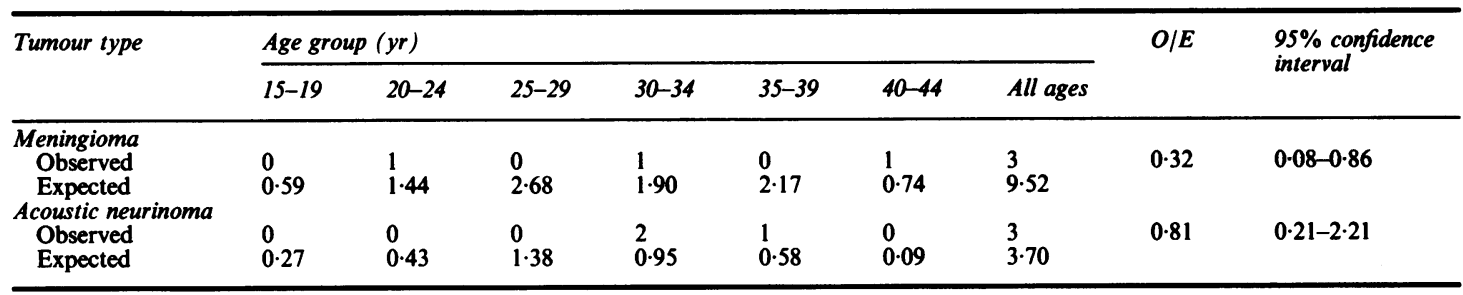

toms prior to diagnosis are shown in table 1. In table 2 these data are summarised to emphasise the temporal relationship between onset of brain tumour symptoms and the beginning of pregnancy. In 11 cases tumour symptoms had unmistakably been present prior to pregnancy. In four cases the beginning of pregnancy was approximately concurrent with the onset of tumour symptoms. In such cases if the onset of the symptoms was insidious, it was difficult to pinpoint the sequence exactly. In nine cases symptoms attributable to the intracranial neoplasm appeared during the pregnancy.

The general population incidence rates for malignant neoplasms of the brain in females aged 15 to 44 years were calculated by 5-year age groups for the periods 1961-1969 and 1970-1979. These figures are shown in table 3. There is no evidence of a difference in incidence of primary malignant intracranial neoplasms during these two periods.

Table 4 shows the observed and expected number of malignant brain tumours in pregnant females for the years 1961 to 1969 and 1970 and 1979 . Uncorrected and corrected observed cases are shown for both time periods. The uncorrected $\mathrm{O} / \mathrm{E}$ ratio overall for the entire time period was 0.36 (22 observed and 61.8 expected). This is significantly less than expected. The $\mathrm{O} / \mathrm{E}$ ratios do not differ for the two time periods.

Incidence rates for meningioma and acoustic neurinoma in the general female population were available only for the years 1970-1979. These rates were applied to the pregnancy years-at-risk, 1961-1979. O/E ratios are presented for 1961-1979 (table 5). Three meningiomas were diagnosed in patients with an existing pregnancy for a significantly low $\mathrm{O} / \mathrm{E}$ ratio of 0.32 . The ratio of observed to expected acoustic neurinomas, $0 \cdot 81$, was not significantly reduced.

\section{Discussion}

The results of the present epidemiological analysis suggest that meningiomas and tumours classified as ICD 191, primary malignant neoplasms of the brain, are diagnosed less often in pregnant women than might have been expected. A number of explanations for these results must be considered. These include (1) overall issues of completeness of brain tumour case reporting to the cancer registry, (2) ascertainment and reporting of pregnancy in tumour patients and (3) the estimation of the expected number of pregnancyassociated brain tumours.

When evaluating the first issue it should be remembered that the reporting of malignant neoplasms in the GDR is obligatory. Based on the high proportion of cases which are histologically confirmed during lifetime and on the low number of cases supported only by the death certificate, the registry system may be regarded as having achieved an acceptable level of completeness and reliability. ${ }^{8}$ In addition to malignant neoplasms of the brain, NCR regulations require that benign intracranial neoplasms be reported. Completeness of diagnosis and reporting of brain neoplasms in the GDR has been evaluated. ${ }^{9-11}$ With the exception of small meningiomas found as incidential findings at necropsy in the elderly, tumours of the CNS are reported quite completely to the cancer registry. Population estimates of the frequency of primary intracranial neoplasms in the female population age 15-44 years are based on near full reporting of diagnosed cases. The proportion of malignant neoplasms of the brain in this age group not histologically verified is approximately $7 \%$.

The second problem concerns the identification and reporting of pregnancy in association with a brain tumour. An observed case as defined here is one in which the patient was pregnant at the time of diagnosis of a malignant intracranial neoplasm. Although pregnancy in association with a brain tumour is a dramatic occurrence it is possible that some pregnant patients were not reported as such. It is also conceivable that a patient was not known to be pregnant at the time of the cancer report. The report is first submitted after the conclusion of the initial course of treatment, usually 8-10 weeks after the initial diagnosis. It remains possible that some patients were neither diagnosed as pregnant prior to treatment for a brain tumour nor before the cancer report was submitted. These factors would lead to under- 
enumeration of pregnancy-associated cases. Although unlikely to occur frequently the magnitude of such misclassification cannot be directly estimated. In fact because of the time lag between clinical diagnosis and treatment and the cancer report some pregnancies which were very early at the time of the preliminary diagnosis have been confirmed and reported.

Yet another group of patients with co-existent pregnancy and brain tumour are excluded by the definition used, namely patients in whom the clinical diagnosis of brain tumour was first entertained postpartum. Since the question on the reporting forms requests information relating to an existing pregnancy only, there would be no way of systematically identifying tumours which were diagnosed postpartum.

The third element which must be considered is the estimation of the expected number of cases. This has two components. The first component, brain tumour incidence rates in the general population, are, as discussed above, a valid measure of tumour occurrence. The second component, the population-at-risk, that is women known to be pregnant, has been estimated from the number of live births. Each birth has contributed nine months of at-risk time to the corresponding maternal five-year age group. This raises a variety of problems. On the one hand it might be argued that nine months is too long since the time at risk to have a pregnancy-associated brain tumour reported is limited to the time that the patient is clinically recognised as pregnant. On the other hand the use of live births to estimate the number of pregnancies ignores pregnancies ending in abortion. Abortion on demand up to the twelfth week has been legal in the GDR since 1972. Assuming an average of 10 weeks at termination, pregnancies ending in voluntary abortion contribute approximately $6.8 \%$ additional pregnancy years-at-risk. A further issue arises from the fact that the population-at-risk, pregnant females, is strongly shifted toward the youngest years in each 5-year age interval after age 15-19 years. In contrast, tumour rates tend to increase with age and are most influenced by the risk experienced by older persons in the 5-year age intervals. The result is that the estimates of expected cases are artifactually increased. We have previously estimated ${ }^{12}$ that this results in an overall inflation of the expected cases by $10 \%$ for cancers of all sites in pregnant females. For malignancies of brain this factor is quantitatively less important since incidence of these tumours is less age dependent than most carcinomas.

Use of general population rates to determine the expected number of brain cancer cases in a selected study population invariably raises questions of appropriateness and comparability. ${ }^{13} \mathrm{~A}$ particular problem results when the cases in the study popu- lation, but not the comparison population are examined and reclassified. For this reason we have presented analyses for malignant neoplasms of the brain using both corrected and uncorrected case series. In both instances $\mathrm{O} / \mathrm{E}$ ratios are significantly reduced.

The magnitude of the reduction in the $\mathrm{O} / \mathrm{E}$ for malignant neoplasms of the brain is so great that the artifacts which have been discussed are unlikely to account completely for the decrease. It is clear from case reports ${ }^{14}$ that some malignant intracranial tumours enlarge with pregnancy. This does not seem to be uniformly, or even usually, the case. Were it so, the increased brain tumour symptoms, occurring at the time of intense medical surveillance, would have resulted in more tumours diagnosed during pregnancy with an elevated $O / E$ ratio rather than the observed substantial reduction.

Similarly, in light of the "general agreement that meningiomas and acoustic neurinomas enlarge in pregnancy", 14 it is surprising that the $\mathrm{O} / \mathrm{E}$ ratio for meningiomas was significantly reduced. Detection of oestrogen and progesterone receptors in some meningiomas ${ }^{15}$ would seem to provide a mechanism for enlargement. The meaning of these receptors is however a matter of dispute as they are not specific for these hormones. ${ }^{16}$

In contrast to the other tumour types, observed cases of acoustic neurinoma were not statistically less frequent than expected. The literature offers a number of examples ${ }^{1718}$ in which pregnancy appeared to have aggravated preexisting audio-visual symptoms or induced seizures in patients with acoustic neurinoma. Kanter ${ }^{19}$ describes eight cases of acoustic neurinoma among three kinships with neurofibromatosis, in which pregnancy seemed to be associated with progression of the brain tumour. Bürger and Kreutzinger ${ }^{20}$ followed three pregnant patients with von Recklinghausen's disease. In the one patient-with acoustic neurinoma there was acute deterioration during pregnancy. The other two patients had peripheral lesions only. In one of these women the neurofibromas enlarged during pregnancy and decreased thereafter. The other was a mother of seven children with a familial history of neurofibromatosis. Her peripheral lesions were said to have declined during each pregnancy, only to enlarge thereafter. It might be speculated that in some patients acoustic neurinomas too might regress or at least not enlarge. Such cases are unlikely to be individually identified or reported. Cases of acoustic neurinoma which are reported to have worsened during pregnancy have for the most part been in patients with hereditary neurofibromatosis. There is at least one example of a patient with neurofibromatosis in whom the course of acoustic neurinomas was not 
affected by pregnancy. Allen $e a^{21}$ reported a patient with a history of familial neurofibromatosis who had experienced five pregnancies from ages 35 to 42 without exacerbation of the mild bilateral hearing loss which was her only symptom. Bilateral neurinomas were subsequently documented at operation.

An alternative explanation for the reduced occurrence of primary intracranial neoplasms in pregnant patients may lie not in the patterns of tumour growth but in reduced fertility of patients with preclinical or undiagnosed brain tumours. Given the doubling times of most intracranial neoplasms it must be assumed that they were present prior to conception. A variety of plausible mechanisms are available to explain a negative association between intracranial neoplasm and pregnancy. These include reduction in libido as a result of constitutional symptoms or direct CNS effects, disturbances in ovulation, conception and implantation, and abnormal embryonic development leading to early, undiagnosed pregnancy loss. Analysis of the reproductive histories of patients with newly diagnosed intracranial neoplasms might provide insight into this aspect of the relationship between brain tumour and pregnancy.

\section{References}

${ }^{1}$ Verhagen A. Tumor und Gravidität. New York: SpringerVerlag, 1974.

${ }^{2}$ Tarnow G. Hirntumor und Schwangerschaft. Z Zbl für Neurochir 1960;20:34-158.

${ }^{3}$ Kloss K. Hirntumor und Schwangerschaft. Wiener $Z$ für Nervenheilkunde und deren Grenzgebiete 1952;5:175-87.

${ }^{4}$ MacLennen R, Muir C, Seinitz R, Winkler A. Cancer Registration and its Techniques. IARC Scientific Publications No 21. Lyon: International Agency for Research on Cancer, 1978.

${ }^{5}$ Editor. Statistisches Jahrnbuch der Deutschen Demokratischen Republik, 17-26. Jahrgang. Berlin: Staatsverlag der Deutschen Demokratischen Republik, 1972-1981.

${ }^{6}$ Armitage P. Statistical Methods in Medical Research. New York: John Wiley and Sons, 1971.

${ }^{7}$ Rothman KJ, Boice JD. Epidemiologic Analysis with a Programmable Calculator. Boston: Epidemiology Resources Inc, 1982.

${ }^{8}$ Muir CS, Waterhouse JAH. Comparability of data and reliability of registration. In: Waterhouse JAH, Muir CS, Shanmugaratnam K, Powell J, eds. Cancer Incidence in Five Continents Vol IV. IARC Scientific Publi- cations No 42. Lyon: International Agency for Research on Cancer, 1982.

9 Jänisch W, Thierbach R, Schreiber D, Lehman S. Meningiome im Greisenalter. In: Tennstedt A, ed. Alternsveränderungen des Zentralnervensystems: Material der 4. Jahrestagung der Gesellschaft für Neuropathologie der $D D R$, Mühlhausen, 10-12 Oktober, 1974. Berlin: Gesellschaft für Neuropathologie der DDR, 1975: 118-20.

${ }^{10}$ Schreiber D, Gerlach H, Jänisch W, Großmann E. Hirntumoren im Senium. In: Tennstedt A, ed. Alternsveränderungen des Zentralnervensystems: Material der 4. Jahrestagung der Gesellschaft für Neuropathologie der $D D R$, Mühlhausen, 10-12 Oktober, 1974. Berlin: Gesellschaft für Neuropathologie der DDR, 1975: 113-17.

11 Jänisch W, Haas JF. Epidemiologic investigation on brain tumors in the GDR: possibilities and limits. Arch Geschwulstforsch 1984;54:243-6.

${ }^{12}$ Haas JF. Pregnancy in association with a newly diagnosed cancer: a population-based epidemiologic assessment. Int J Cancer 1984;34:229-35.

${ }^{13}$ Hannis NM, Holmes TM, Newill VA, Smith FR, Smith LG. Brain cancer: issues and dilemmas. In: Selikoff IJ, Hammond EC, eds. Brain Tumors in the Chemical Industry. Ann NY Acad Sci 1982;381:83-90.

${ }^{14}$ Michelsen JJ, New PFJ. Brain tumor and pregnancy. J Neurol Neurosurg Psychiatry 1969;32:305-7.

${ }^{15}$ Markwalder TM, Zava DT, Goldhirsch A, Markwalder RV. Estrogen and progesterone receptors in relation to clinical and pathologic features. Surg Neurol 1983; 20:42-7.

${ }^{16}$ Schwartz MR, Randolph RL, Cech DA, Rose JE, Panko WB. Steroid hormone binding macromolecules in meningiomas: failure to meet criteria of specific receptors. Cancer 1984;53:922-7.

${ }^{17}$ Alliez J, Masse JL, Alliez B. Tumeurs bilatérales de l'acoustique et maladie der Recklinghausen observées dans plusieurs générations. Considérations sur les tumeurs de l'acoustique héréditaires (1). Rev Neurol (Paris) 1975;131:545-58.

${ }^{18}$ Unger RR, Siedschlag WD, Bayer H. Raumfordernde intrakranielle Prozesse und Schwangerschaft. Zeutralbl Neurochir 1976;37:177-89.

${ }^{19}$ Kanter WR, Elridge R, Fabricant R, Allen JC, Koerber T. Central neurofibromatosis with bilateral acoustic neuroma: genetic, clinical and biochemical distinctions from peripheral neurofibromatosis. Neurology (Minneap) 1980;30:851-9.

${ }^{20}$ Bürger G, Kreutzinger E. Beitrag zu Morbus Recklinghausen und Schwangerschaft. Z Ärzt Fortbild 1966;60:384-6.

${ }^{21}$ Allen J, Eldridge R, Koerber T. Acoustic neuroma in the last months of pregnancy. Am J Obstet Gynecol 1974;119:516-20. 